\begin{tabular}{|ccc}
\hline Sournals & $\begin{array}{c}\text { INTERNATIONAL JOURNAL OF } \\
\text { ORGANIZATIONAL LEADERSHIP }\end{array}$ & $\begin{array}{c}\text { INDUSTRIAL } \\
\text { MANAGEMENT } \\
\text { INSTITUTE }\end{array}$ \\
\hline \hline
\end{tabular}

\title{
The relationship between job rotation and duty commitment of employees: A case study among employees of Islamic Azad University, District 13
}

\author{
Davar Abouzari Arasi ${ }^{*}$, Mohammad Bagher Alizadeh Aghdam² \\ ${ }^{1}$ M.A. Student of Educational Management, Marand Branch, Islamic Azad University \\ ${ }^{2}$ Faculty Member at Tabriz University
}

\begin{abstract}
Keywords:

Organizational

Commitment, Competitive

Advantage, Duty

Commitment, Job Rotation

Received

05 September 2015

Received in revised form

03 March 2016

Accepted

01 April 2016

Correspondence:

abouzari_davar@yahoo.com

Organizational commitment is very important, as it can lead to competitive advantage and financial success and it is considered a key of competitive advantage. Duty commitment is a dimension of organizational commitment and it refers to the employee's sense of obligation to remain in the organization. In this dimension of commitment, individuals consider their responsibility to continue working in organization and thereby, discharge their duties to organization. An approach to improve duty commitment is job rotation, because an individual will work with interest, the gap between individual objectives and organizational objectives will be narrowed and organizational commitment will be increased. The main subject in this study is to answer the question that how is the relationship between job rotation and duty commitment of employees of Islamic Azad University, district 13 ? This study is applied and descriptive in terms of objective and is conducted by surveying. The statistical population of this study includes non-academic staff members of Islamic Azad University. Pearson correlation coefficient is used in data analysis and results indicated that there is a significant correlation between job rotation and affective duty commitment.
\end{abstract}

(C)AIMI Journals

\section{Introduction}

Efficiency and development of any organization depends heavily on true application of human source. One of the most important motivational elements is organizational commitment which currently spread in industrial and organizational psychology through the West in huge amounts (Jafari Ghoshchi, 2001). 
Job rotation is an approach to increase organizational commitment of employees. Since the individual works with interest, the gap between individual and organizational objectives is narrowed and organizational commitment is increased.

Applying job rotation approach in organization can increase organizational commitment. As the individual works with interest, the gap between individual and organizational objectives is narrowed and organizational commitment is increased. On the other hand, transposition of employees into different positions will prorate difficulties and problems of special jobs between individuals and will minimize complaints about them. Other positive consequences of job rotation are increasing job satisfaction, creating job sensitivity, and reducing fatigue of employees.

Duty commitment is a dimension of organizational commitment which refers to the employee's sense of obligation to remain in organization. In this dimension of commitment, individuals consider their responsibility to continue working in organization and thereby, discharge their duties to organization (Moghimi, 2004).

Regarding the decrease of student population in Islamic Azad University and the decrease of employment as a result of unreliability in number of students entering to the university in future years, need for using job rotation in Islamic Azad University has increased. Therefore, concerning the great importance of duty commitment in organizations, this study attempts to investigate the effects of job rotation on duty commitment of employees of Islamic Azad University, district 13. The main subject in this study is to answer the question that how is the relationship between job rotation and duty commitment of employees of Islamic Azad University, district 13 ?

This study aimed to investigate the relationship between job rotation and duty commitment and also it tried to explore various views of employees of Islamic Azad University, district 13 about duty commitment in terms of variables including gender, age, education degree, and work experience.

\section{The Literature Review}

Rezaei (2009) aimed to investigate the relationship between the job rotation and organizational commitment of post office staff of West Azerbaijan Province. He concluded that there was a significant relationship between the job rotation and continuous emotional commitment and normative commitment of employees.

Sardar and Azadeh (2012) in a research under the title of "The effect of psychological contracts on trust and commitment of employees in an insurance company" argued that there was a significant relationship between the formation of the psychological contract and trust and commitment. In addition, the significant relationship between the commitment and trust was apparent.

Shabani, Hosseinzedeh, and Ahmadi (2012) in investigating the relationship between the organizational justice and organizational commitment in the Khorasan Razavi tax affairs office stated that there was a significant positive correlation between the organizational justice and organizational commitment dimensions.

Rasouli (2014) in his research aimed to discuss the effects of job rotation patterns on employees' performance in the Keshavarzi Bank of Guilan given the diversity of skills and job 
satisfaction and providing the effective guidelines for managers. The results indicated that job rotation directly affected the job performance. Moreover, job rotation had impact on the performance of job, job satisfaction, and skill variety.

Sweeney (2008) studied the effect of job rotation on the performance of the managers of defense industries in the University of Texas and he concluded that there was a positive relationship between the job rotation, employees' satisfaction, organizational commitment, work quality of managers, and teamwork of managers.

Adomi (2006) indicated that job rotation could be raised as an opportunity for learning more and avoiding depression among known employees.

The study results of Ortega (2001) entitled as the "Job rotation as a learning mechanism" showed that advantages and disadvantages of job rotation can be considered as a mechanism to check the productivity and efficiency of employees in different jobs and forms. The findings revealed that the use of new technologies was effective than the job rotation as a mechanism.

\section{Method}

This study, in terms of objective, is applied and aimed at investigating the relationship between job rotation and organizational commitment which is a correlational research. In a correlational research, exploring relationship between two groups of data is concerned. Therefore, the present study regarding the nature and method of study is a correlational one.

The statistical population of study involves the employees of Islamic Azad University, district 13 including 35 branches and centers with 2343 employees which 307 of them are female $(13.1 \%)$ and 2036 are male $(86.9 \%)$.

In this study, simple random sampling was conducted with regard to the ratio of employees in each branch and university center to total employees of Islamic Azad University and finally the sampling size included 330 people.

Hybrid questionnaire, developed by Mowday, Steers, and Porter (1979) and Meyer and Allen (1997) was used to measure the organizational commitment and the questionnaire developed by Soltani (2000) was used to measure the job rotation. Both questionnaires were confirmed by the supervisor and related experts which contributes to the validity of questionnaire.

Pearson correlation coefficient is used in inferential level. Following this, correlation coefficient indicated intensity and kind of relationship (direct or inverse) between two variables. As data of this study is quantitative, Pearson correlation coefficient is used to test the relationship between data.

\section{Describing Employees' Characteristics}

This section includes information about gender, age, education degree, work experience, and number of job rotations in the organization about the subjects of study. The results are summarized as followings:

Gender Distribution: Based on the collected data, it is observed that 144 people were female and 186 people were male who respectively includeed $43.2 \%$ and $56.8 \%$ of the whole sample of employees of Islamic Azad University, district 13, and the highest frequency is related to men. 
Age Distribution: It is perceived that 19 people (5.6\%) were from 20 to 30 years and following this, 156 people (46.7\%), 89 people (27.4\%), 42 people $(13.3 \%), 12$ people $(3.5 \%)$, and 12 people (3.5\%) were from 31 to 35 years, 36 to 40 years, 41 to 45 years, 46 to 50 years, respectively and 12 people $(3.5 \%)$ were older than 50 years old. The highest frequency is related to 31 to 35 years old with $46.7 \%$ and the lowest frequency is related to 46 to 50 years old and higher.

Distribution in terms of Employees' Education Degree: Based on the collected data, it is noticed that 29 people $(8.5 \%)$ had high school diploma, 16 people $(4.7 \%)$ had associate degree, 246 people $(74.3 \%)$ had B.A., and 29 people (12.5\%) had M.A. and higher degrees. The highest frequency is related to B.A. and the lowest frequency is referred to associate degree.

Employees' Work Experience Distribution: Based on the collected data, it is observed that 207 people $(62.9 \%)$ had 7 to 11 years of work experience, 54 people $(15.8 \%)$ had 12 to 15 years, 24 people ( $7.0 \%)$ had 16 to 19 years, 27 people $(7.6 \%)$ had 20 to 23 years, and 18 people $(6.7 \%)$ had 24 to 28 years of work experience. The highest frequency is related to people with 7 to 11 years of work experience and the lowest frequency is related to those who have 24 to 28 years of work experience.

Employees' Job Rotation Distribution in the Organization: It is perceived that 219 people $(64.2 \%)$ had 1-3 times of job rotation, 74 people $(22.7 \%)$ had 4-6 times, and 37 people $(10.9 \%)$ had $7-10$ times of job rotation. The highest frequency is related to $1-3$ times and the lowest frequency is related to 7-10 times.

Descriptive Statistics on Affective Commitment: Based on collected data, it is observed that mean of affective commitment is 40.26 with standard deviation of 6.82 and minimum of 26 and maximum of 86 .

Descriptive Statistics on Job Rotation in the Organization: Mean job rotation is 2.18 with standard deviation of 1.16 and minimum of 1 and maximum of 5 .

Descriptive Statistics on Interest Level of Employees in Job Rotation: Mean interest in job rotation is 2.70 with standard deviation of 1.40 and minimum of 1 and maximum of 5 .

Table 1

Kolmogorov-Smirnov Test to Determine Normality in Distribution of Relationship between Job Rotation and Organizational Commitment of Employees

\begin{tabular}{lcccc}
\hline & Affective Dimension & Duty Dimension & Continuity Dimension & Job Rotation \\
\hline Kolmogorov-Smirnov & 1.450 & 1.955 & 1.719 & 1.935 \\
Directional significance level & 0.060 & 0.07 & 0.066 & 0.065 \\
\hline
\end{tabular}

\section{Results}

The hypotheses of study are investigated through appropriate statistical tests. Firstly, Kolmogorov-Smirnov test was used to determine normality in scores distribution of relationship between job rotation and organizational commitment of Islamic Azad University's employees and their subscales.

Table 1 and Kolmogorov-Smirnov test indicates that score distribution for job rotation and organizational commitment is normal with test value of $\mathrm{k}-\mathrm{z}=1.385$ and significance level of $\mathrm{p}=.146$. As significance level is higher than 0.05 , parametric test was used to answer research questions. Moreover, it is indicated that score distribution in subscales of job rotation and 
organizational commitment is normal based on Kolmogorov-Smirnov test value; since their significance levels are higher than 0.05 , that is, there is no difference between data distribution and normal distribution.

\section{Test of Relationship between Job Rotation and Duty Commitment}

According to the information given in Table 2, Pearson correlation coefficient is used to investigate the relationship between job rotation and duty commitment of employees of Islamic Azad University, district 13 and the value of correlation is computed as $\mathrm{r} 0.325$, and according to significance level of $\alpha=0.01$, null hypothesis (H0) is rejected. Therefore, there is a significant correlation between job rotation and duty commitment of employees. In addition, based on value of Pearson correlation coefficient, this relationship is direct with moderate intensity.

Table 2

Relationship between Job Rotation and Duty Commitment of Employees of Islamic Azad University, district 13

\begin{tabular}{ccc}
\hline Duty Commitment & Pearson Correlation Coefficient & \\
\hline 0.325 & $\mathrm{R}$ & Job Rotation \\
0.000 & Sig. & \\
330 & $\mathrm{~N}$ & $\mathrm{P}$ \\
0.01 & $\mathrm{P}$ & \\
\hline
\end{tabular}

$\mathrm{T}$ test is used to evaluate the differences between the employees' views of Islamic Azad University, district 13 about job rotation in terms of gender which is described in Table 3.

Table 3

Evaluating Differences between Employees' Views about Job Rotation in Terms of Gender

\begin{tabular}{ccccccc}
\hline Dependent Variable & Gender & Number & Mean & Mean Difference & $\mathrm{t}$ & Significant Difference \\
\hline Job Rotation & Woman & 144 & 42.694 & -1.71550 & -1.991 & 0.40 \\
& Man & 186 & 43.7849 & & &
\end{tabular}

According to the information presented in Table 3, mean job rotation for women is 42.0694 and with -1.71550 of mean difference, it is less than mean job rotation for men which is 43.7849. Evaluating significance level calculated by independent $t$-test and comparing mean job rotation for women and men, it is indicated that significance level is 0.40 and is higher than 0.05 . Therefore, there is no statistically significant difference between employees' views about job rotation of Islamic Azad University, district 13.

Analysis of variance (ANOVA) test was used to evaluate the differences between the differences of the employees' views of Islamic Azad University, district 13 about job rotation in terms of age which is summarized in Table 4.

Table 4

Homogeneity of Variance Test for Age

\begin{tabular}{cccccc}
\hline Variance & Sum of Squares & Degrees of Freedom & Mean Squares & F & Significance Level \\
\hline Inter-group & 414.032 & 5 & 82.806 & 1.369 & 0.036 \\
In-group & 19597.532 & 324 & 60.486 & & \\
Total & 20011.564 & 329 & & & \\
\hline
\end{tabular}


Based on information achieved by ANOVA test for two variables of age and job rotation and based on significance level of 0.036 for F-test which is higher than 0.01 , there is no significant difference between employees' views about job rotation in terms of age and this hypothesis is rejected.

ANOVA test was used to evaluate the differences between the employees' views of Islamic Azad University, District 13 about the job rotation in terms of education degree and it is summarized in Table 5.

Table 5

Homogeneity of Variance Test for Education Degree

\begin{tabular}{lccccc}
\hline Variance & $\mathrm{S}$ & Degrees of Freedom & Mean Squares & F & Significance Level \\
\hline Inter-Group & 630.775 & 3 & 210.258 & 3.537 & 0.004 \\
In-Group & 19380.788 & 326 & 59.450 & & \\
Total & 20011.564 & 329 & & & \\
\hline
\end{tabular}

Based on information achieved by ANOVA test for two variables of education degree and job rotation and based on significance level of 0.004 for F-test which is lower than 0.01 , there is significant difference between employees' views about job rotation in terms of education degree and this hypothesis is confirmed.

ANOVA test was applied to evaluate the differences between employees' views of Islamic Azad University, district 13 about the job rotation in terms of work experience and the results are represented in Table 6 .

Table 6

Homogeneity of Variance Test for Work Experience

\begin{tabular}{lccccc}
\hline Variance & Sum of Squares & Degrees of Freedom & Mean Squares & F & Significance Level \\
\hline Inter-Group & 557.349 & 4 & 139.337 & 2.228 & 0.006 \\
In-Group & 19454.214 & 325 & 59.859 & & \\
Total & 20011.564 & 329 & & & \\
\hline
\end{tabular}

Considering the information attained by ANOVA test for two variables of work experience and job rotation and based on significance level of 0.006 for F-test which is lower than 0.01 , there is significant difference between employees' views about job rotation in terms of work experience and this hypothesis is confirmed.

T-test was used to evaluate the differences between the employees' views of Islamic Azad University, district 13 about the duty commitment in terms of gender which is summarized in Table 7.

Table 7

Evaluating Differences between Employees' Views about Duty Commitment in Terms of Gender

\begin{tabular}{ccccccc}
\hline Dependent Variable & Gender & Number & Mean & Mean Difference & $\mathrm{t}$ & Significant Difference \\
\hline Organizational commitment & Woman & 144 & 68.0139 & -1.87321 & -1.661 & 0.002 \\
& Man & 186 & 69.8871 & & & \\
\hline
\end{tabular}

Based on information in Table 7, mean duty commitment for women is 68.0139 and with 1.87321 of mean difference, it is less than the mean of affective commitment for men which is 
69.8871. Evaluating significance level achieved by independent $t$-test and comparing mean organizational commitment for women and men, it is indicated that significance level is 0.002 and it is lower than 0.05 . Therefore, there is significant difference between employees' views about the affective commitment of Islamic Azad University, district 13 and this hypothesis is confirmed.

ANOVA test was used to evaluate the differences between the employees' views of Islamic Azad University, district 13 about the duty commitment in terms of age which is presented in Table 8

Table 8

Homogeneity of Variance Test for Age

\begin{tabular}{lccccc}
\hline Variance & Sum of Squares & Degrees of Freedom & Mean Squares & F & Significance Level \\
\hline Inter-Group & 627.998 & 5 & 125.600 & 1.214 & 0.302 \\
In-Group & 33511.399 & 324 & 103.430 & & \\
Total & 34139.397 & 329 & & & \\
\hline
\end{tabular}

Regarding the information achieved by ANOVA test for two variables of age and duty commitment and based on significance level of 0.302 for F-test which is higher than 0.01 , there is no significant difference between employees' views about the affective commitment in terms of age. To this end, this hypothesis is rejected.

Evaluating Differences between Employees' Views of Islamic Azad University, District 13 about Duty Commitment in Terms of Education Degree

ANOVA test was used to evaluate this hypothesis and the results are summarized in Table 9.

Table 9

Homogeneity of Variance Test for Education Degree

\begin{tabular}{lccccc}
\hline Variance & Sum of Squares & Degrees of Freedom & Mean Squares & F & Significance Level \\
\hline Inter-Group & 135.155 & 3 & 45.052 & 0.432 & 0.730 \\
In-Group & 34004.242 & 326 & 104.307 & & \\
Total & 34139.397 & 329 & & & \\
\hline
\end{tabular}

Considering the information achieved by ANOVA test for two variables of education degree and duty commitment and based on significance level of 0.730 for F-test which is higher than 0.01 , there is no significant difference between employees' views about the affective commitment in terms of education degree; so, this hypothesis is rejected.

ANOVA test came into use to evaluate the differences between employees' views of Islamic Azad University, district 13 about duty commitment in terms of work experience which is summarized in Table 10.

Table 10

Homogeneity of Variance Test for Work Experience

\begin{tabular}{lccccc}
\hline Variance & Sum of Squares & Degrees of Freedom & Mean Squares & F & Significance Level \\
\hline Inter-Group & 728.130 & 4 & 182.033 & 1.771 & 0.134 \\
In-Group & 33411.267 & 325 & 102.804 & & \\
Total & 34139.397 & 329 & & & \\
\hline
\end{tabular}


Based on information achieved by ANOVA test for two variables of work experience and duty commitment and based on significance level of 0.134 for F-test which is higher than 0.01 , there is no significant difference between employees' views about duty commitment in terms of work experience and this hypothesis is rejected.

\section{Discussion and Conclusion}

Job rotation is an approach to develop human resources and boost morale and commitment of employees which results in improvement of views and skills of employees. Job stability can lead to job burnout, boredom of employees, exhaustion, loss of identity in person, isolation of individual and organizational objectives, and resistance to any change in job. The strategy to overcome these problems may be job rotation. In the present study, studying the relationship between job rotation and affective commitment of employees of Islamic Azad University, district 13 was conducted and required data was collected and analyzed through distributing questionnaires among selected samples from statistical population of employees. Finally, the relationship between job rotation and affective commitment of employees was confirmed as following.

There is a significant correlation between job rotation and duty commitment (normative commitment) of employees. Duty commitment (normative commitment) reflects a sense of accountability for continuing work in organization and employees with a high level duty commitment (normative commitment) feel that they should remain in the organization. Duty commitment leads to remaining in the organization due to the sense of loyalty or accountability. Individual feels responsibility towards investments which have been made by organization.

In the second hypothesis, the differences in views of employees of Islamic Azad University, district 13 were obtained about the job rotation in terms of variables, namely gender, age, education degree, and work experience and results indicated that statistically, there is no significant difference in views of employees of Islamic Azad University, district 13 about the job rotation in terms of gender, age, education degree, and work experience.

In the third hypothesis, differences in views of employees of Islamic Azad University, district 13 were investigated about the affective commitment in terms of variables (gender, age, education degree and work experience) and results demonstrated that there is a significant difference in views of employees of Islamic Azad University, district 13 about the affective commitment in terms of gender. Statistically, it is concluded that there is no significant difference in views of employees of Islamic Azad University, district 13 about the affective commitment in terms of age, education degree, and work experience.

In fourth hypothesis, the differences in views of employees of Islamic Azad University, district 13 were achieved about job rotation in terms of variables including gender, age, education degree, and work experience and results indicated there is no significant difference in views of employees of Islamic Azad University, district 13 about job rotation in terms of gender, age, education degree, and work experience.

In the fifth hypothesis, the differences in views of employees of Islamic Azad University, district 13 were investigated about organizational commitment in terms of variables such as gender, age, education degree, and work experience. According to the results, it is stated that 
there is a significant difference in views of employees of Islamic Azad University, district 13 about organizational commitment in terms of gender; there is no significant difference in views of employees of Islamic Azad University, district 13 about organizational commitment in terms of age, education degree, and work experience.

Third hypothesis suggests that there is a significant correlation between job rotation and duty commitment (normative commitment) of employees. Therefore, it is necessary to measure employees' satisfaction in job rotation frequently to keep employees in the organization and create a positive view in them.

As it is indicated in hypotheses 4 and 5, there is no difference in employees' views about job rotation in terms of gender, age, education degree, and work experience. Therefore, we can consider the whole organization alike in giving necessary training and applying job rotation in the organization. However, men's views about organizational commitment were different from women's which demonstrated that we should always differentiate between two groups of employees (men and women).

\section{References}

Adomi, E. E. (2006). Job rotation in Nigerian university libraries. Library Review, 55(1), 66-74.

JafariGhoshchi, B. (2001). Job rotation: An ideal or a necessity. Tadbir Magazine, 122, 109-112.

Meyer, J. P., \& Allen, N. J. (1997). Commitment in the workplace: Theory, research and application. Thousand Oaks, CA: SAGE Publications.

Moghimi, S. (2004). The organization and management: A research approach. Tehran, Iran: Termeh Book.

Mowday, R. T., Steers, R. M., \& Porter, L. W. (1979). The measurement of organizational commitment. Journal of Vocational Behavior, 14(2), 224-247.

Ortega, J. (2001). Job Rotation as a Learning Mechanism. Management Science, 47(10), 1361-1370.

Rasouli, S. (2014). Investigating the effect of job rotation on presented performance by taking into account the diversity of skills and job satisfaction of bank employees (Unpublished master's thesis). Islamic Azad University South Tehran Branch, Tehran.

Rezaei, N. (2009). Investigating the relationship between the job rotation and organizational commitment of post office staff of West Azerbaijan Province. Unpublished master's thesis. Islamic Azad University, Benab Branch, Tabriz.

Sardar, S., \& Azadeh, P. (2012). The effect of psychological contracts on trust and commitment of employees in an insurance company. Insurance Journal, 1, 109-133.

Shabani, A., Hosseinzadeh, A., \& Ahmadi, Y. (2012). The relationship between the organizational justice and organizational commitment in the Khorasan Razavi tax affairs office. Tax Magazine, 13, 104-119.

Soltani, I. (2000). The role of job rotation in developing human resources. Tadbir Magazine, 101, 33-35.

Sweeney, D. L. (2008). Job rotation effect on the performance of defense industry executives (Unpublished doctoral dissertation). University of Texas, America. 